\title{
«КОЛИ НЕ ЗБЕРЕМО ЩО НАЙМЕНШЕ 10000 ПІДПИСІВ, ТО ВЕСЬ НАШ РОЗМАХ ПРОТИ МОСКАЛЯ ПІДЕ НА МАРНО...» (УЧАСТЬ ПОЛОНЕНИХ УКРАЇНЦІВ ТАБОРУ РАШТАТ У ЗАГАЛЬНОРО- СІЙСЬКОМУ РЕВОЛЮЦІЙНОМУ РУСІ НАВЕСНІ 1917 р.)
}

\author{
Ігор Срібняк ${ }^{1}$ Юлія Назарук² \\ ${ }^{1}$ Київський університет імені Бориса Грінченка \\ e-mail: i.sribniak@kubg.edu.ua \\ ORCID: https://orcid.org/0000-0001-9750-4958
}
2Мелітопольський коледж Таврійського державного агротехнологічного університету імені Дмитра Моторного e-mail: nazaruk05.06@gmail.com
ORCID: https://orcid.org/0000-0002-4902-1764

У статті йдеться про проведення збору підписів полонених вояків-украӥнців з табору Раштат (Німеччина) для уповноваження О. Скорописа-Йолтуховського представляти їх права та інтереси перед російським Тимчасовим урядом. 3 метою роз'яснення цього у таборовій газеті «Розсвіт» був опублікований заклик до полонених внести своє ім'я та прізвище до спеціальних підписних листів, які прикладались до кожного примірника цього випуску часопису. 3 табору до робітничих команд виїхали українські активісти, завданням яких стало проведення агітаційної акції у середовищі таборян. Їх заходами уповноваження О. Скоропису-Йолтуховському підписали 8829 полонених, що засвідчило їх достатньо високий рівень національно-громадської освіченості.

Ключові слова: полонені, табір, газета, уповноваження, О. Скоропис-Йолтуховський, Раштат, Німеччина

Окремі аспекти функціонування української громади «Самостійна Україна» у таборі Раштат на сьогодні $\epsilon$ вже значною мірою розроблені у силу того, що на відміну від інших таборів (Вецляра і Зальцведеля) до вивчення ії історії ще у 1919 р. звернувся О. Терлецький, заходами якого був підготовлений та опублікований грунтовний нарис з історії розвитку згадуваної громади ${ }^{1}$. Ця книга стала першим, і майже на ціле століття єдиним, синтетичним дослідженням в якому було достатньо повно проаналізовано всі прояви життєдіяльності полонених українців у згадуваному таборі. Разом з тим ії автор не мав можливості залучити весь джерельний матеріал $з$ даної проблеми.

У середині 1990-х рр. національно-просвітницька діяльність полонених вояківукраїнців цього табору опинилась у полі уваги І.Срібняка². Проблематика табору Раштат розроблялась ним і пізніше ${ }^{3}$. Деякий час патріотично-освідомлююча діяль-

\footnotetext{
1 Терлецький О. Історія української громади в Раштаті 1915-1918. Київ-Ляйпціг, 1919. Т. 1. 429 с.

2 Срібняк І. Полонені українці в Австро-Угорщині та Німеччині (1914-1920 рр.). Київ, 1999. С. 72-92.

${ }^{3}$ Срібняк I. Національно-організаційна та культурно-просвітницька діяльність полонених українців у таборі Раштат (Німеччина) у 1915-1917 pp. // Сіверянський літопис. Чернігів, 2014. № 6 (120). Листопад-грудень. С. 309-324; Срібняк І. Новітня «Запорізька Січ» на чужині (творення парамілітарних структур в українському таборі Раштат, 1916 р.) // Емінак: науковий щокварта-
} 
ність СВУ в Раштаті була об’єктом дослідницьких зацікавлень Л. Кривошеєвої, підсумком чого став захист нею дисертаційного проекту4. У контексті вивчення політичної біографії О.Скорописа-Йолтуховського до цієї тематики зверталась і Ю. Назарук5. Але, вочевидь, усіх згаданих вище праць $€$ недостатньо для витворення комплексної історії української громади у таборі Раштат, що спонукає сучасних дослідників до продовження наукової розробки даної проблеми.

$* * *$

Лютнева революція у Росії стала найпотужнішим каталізатором процесу формування національної самосвідомості у полонених вояків-українців. Падіння російського царату звільнило значну частину таборян від відчуття страху перед неодмінними репресіями, які їх очікували після повернення додому. 3 огляду на це українська пропаганда набула у цей час значно потужнішого звучання, привертаючи до складу громади «Самостійна Україна» все нових симпатиків українства.

Перебуваючи під вражінням блискавичного падіння монархії та трансформації імперії у республіку, керівник Берлінської централі Союзу визволення України (організації, яка спрямовувала національно-освітню роботу у таборах) О.СкорописЙолтуховський 31 березня 1917 р. звернувся до таборян із закликом надати йому уповноваження представляти їх інтереси перед російським Тимчасовим урядом. У його листі, адресованому Генеральній старшині громади «Самостійна Україна» у Раштаті, містилось доручення опублікувати у таборовій газеті «на цілу першу сторінку» текст відозви, при чому наклад цього номера часопису мав скласти 6000 примірників 6 (майже втричі більшим ніж наклад звичайного числа - aвm.).

У цьому документі було сформульовано чотири соціально-політичні вимоги, на основі дотримання яких мали будуватись майбутні українсько-російські взаємини: «Щоби в основу нових, як тимчасових порядків, так і нових основних законів, заложено й переведено до краю повне народоправє (повнота власти народові); щоби на всім просторі, заселеним українським народом, привернені були назад основи Переяславського договору 1654 року, підступно под[т]оптані та знищені московськими царями, і щоби права инших недержавних народів Росії були забезпечені основними законами, щоби селянству українському привернено назад відняті царями в україн-

льник. 2017. № 1 (17) (січень-березень). Т. 1. С. 80-85; Срібняк І. Полонені офіцери-українці царської армії в таборі Раштат (Німеччина) у 1916 р.: громадський та особистісний вимір таборового повсякдення // Емінак: науковий щоквартальник. 2017. № 4 (20) (жовтень-грудень). Т. 1. С. 3540; Срібняк I. «Вже не одиниці з поміж Українців, але тисячі...» (діяльність громади «Самостійна Україна» в таборі Раштат у першій половині 1918 р.) // Межибіж: науковий вісник з проблем регіональної історії і пам’яткознавства. Межибіж, 2017. № 1. Ч. 1. С. 345-352; Sribniak I. Działalność narodowo-organizacyjna Związku Wyzwolenia Ukrainy w obozie jeńców armii cesarskiej Rastatt w Niemcach (1915-1918) // Wschodnioznawstwo 2018. Wrocław, 2018. S. 231-242.

${ }^{4}$ Кривошеєва Л. Національно-просвітня діяльність Союзу визволення України в таборах військовополонених українців (1914-1918 рр.). Дис.... канд. іст. наук: 07.00.01 - Історія України. Запоріжжя, 2009. 242 с.

5 Назарук Ю.С. Зростання політичної свідомості полонених українців у 1917 р.: від автономізму до самостійності // Пам'ятки: археографічний щорічник. Київ, 2009. Т. 10. С. 62-68; Назарук Ю.С. Організаційно-політична діяльність Олександра Скорописа-Йолтуховського серед полонених українців у Німеччині та Австро-Угорщині (1914-1917 рр.) // Наукові записки Інституту політичних і етнонаціональних досліджень. Київ, 2004. Вип. 26. С. 126-132.

6Центральний держархів вищих органів влади та управління України (ЦДАВО України). Ф. 4406. Оп. 1. Спр. 39. Арк. 8. 
ського народу й роздаровані царським слугам землі; щоби в інтересі розпочатого народом великого діла був заключений правительством революції як найшвидше мир на основах, які гарантували би всім народам Европи вільний розвиток»7. Як зазначалось у цитованому листі О. Скорописа-Йолтуховського, ці положення були взяті ним з меморіалу «Революційному Правительству Росії» (підписання якого було ініційоване Головною Українською Радою табору Фрайштадт в Австро-Угорщині), при чому - за його ж визнанням - 2-й пункт був дуже невдалим, і тому мав би бути «стилізований инакше»8.

3 висоти сьогодення $€$ всі підстави стверджувати, що всі ці вимоги апріорі не могли бути виконані політичним проводом «революційної» Росії, яка не збиралася передавати владу народові (але зробила все аби пізніше владу узурпували більшовики), не уклала миру та продовжувала війну до «переможного кінця», не могла через свою анемічність справедливо вирішити земельне питання, і тим більше не збиралась у відносинах з Україною повертатись до «основ Переяславського договору 1654 року» та забезпечувати хоч у мінімальній мірі «права инших недержавних народів». Попри всі революційні перетворення у Росії - не змінювалась і не могла змінитись природа їі великодержавно-імперіалістичної влади, як і не могло відбутись жодних зрушень на краще психології основної маси прибічників більшовизму, визначальними рисами яких були плебейство, агресивність, знахабнілість, сліпа віра у своїх підступних вождів.

Зрозуміло, що таборяни не могли цього передбачати, відтак на виконання розпорядження О.Скорописа-Йолтуховського 2 квітня був опублікований номер газети «Розсвіт» з відозвою9 , і вже наступного дня його було розіслано на робітничі команди. У часопису було розміщено й звернення підтримати своїм підписом цю кампанію і тих полонених українців, які не були приписані до жодного з українських таборів. О. Скоропис-Йолтуховський закликав таборян «пустити в рух всі свої сили і організаційний досвід»10, щоб швидко й успішно провести агітаційно-роз'яснювальну кампанію у середовищі полонених, переважна більшість яких перебувала поза табором. Але через відсутність «українського референта» капітана Швайцера у Раштаті, Генеральна старшина (вищий виконавчий орган громади - aвm.) не могла негайно відрядити до робітничих команд «мужів довір'я» й українських активістів з метою роз'яснення суті відозви та для збору підписів ${ }^{11}$.

3 квітня 1917 р. О. Скоропис-Йолтуховський відіслав до Раштату своє власне звернення (для публікації у таборовій газеті ${ }^{12}$ ), яким переконував полонених, що їх голос «мусить почути ціла Україна, ціла московська держава», а задля того його належить відрядити для переговорів з Тимчасовим урядом. Це твердження він обгрунтовував тим, що СВУ вже обстоював права полонених українців перед урядами центральних і нейтральних держав, між тим - після повалення царату, на думку 0. Скорописа-Йолтуховського, «наступила пора, коли Союз визволення України, виповняючи свій обовязок перед нашим народом, мусить виступити в обороні його

\footnotetext{
7 Ibid. Арк. 9.

8 Ibid. Арк. 9.

9 До товаришів полонених ріжних таборів, та робітничих команд // Розсвіт (Раштат). 1917.

3 (4) квітня. Ч. 21 (86). С. 2.

10 ЦДАВО України. Ф. 4406. Оп. 1. Спр. 39. Арк. 10.

11 Ibid. Арк. 16.

12 Скоропис-Йолтуховський О. До всіх громадян Раштатського табору // Розсвіт (Раштат). 1917.

3 квітня. Ч. 21 (86). С. 1.
} 
прав і перед московським правительством». Не розуміючи природи революційних подій у Росії, О.Скоропис-Йолтуховський абсолютно безпідставно вважав, що 3 огляду на виникнення «з революції народних мас» російського Тимчасового уряду, останній «мусить рахуватися з волею народних мас»13.

Можна тільки дивуватись тій політичній наївності, яку продемонстрував у цьому питанні О.Скоропис-Йолтуховський - без сумніву дуже досвідчений український громадський діяч і політик. Єдиним поясненням цьому може хіба слугувати його сліпа віра у добру волю російської демократії зразка 1917 р., яка напевно-що грунтувалась на його колишніх зв'язках з російськими революціонерами на початку ХХ ст. (у свій час 0.Скоропис-Йолтуховський належав до складу «Соціал-демократичної спілки», яка на автономних засадах входила до Російської соціал-демократичної робітничої партії- $а в т$.$) .$

Можливо що такі помірковані (але все одно нездійсненні) вимоги до російського Тимчасового уряду були обумовлені тактичними міркуваннями, намаганням домогтись від нього хоча би мінімальних поступок, бо заявляти про від'єднання від Росії і сподіватись отримати на це згоду було з самого початку приречене на категоричну відмову. Найгіршим було те, що О. Скоропис-Йолтуховський не розумів головного безперспективності апеляцій до російських політичних еліт щодо самовизначення українських земель, які апріорі розглядались ними тільки у нерозривному зв'язку з метрополією.

Між тим організаційна фаза збору підписів успішно тривала - 3 квітня 1917 р. представники громади (т. зв. - «мужі довір'я») отримали відозви та підписні листи і були проінструктовані зібрати якомога більше підписів серед полонених, для чого вони мали відвідати максимальну кількість робітничих команд. Для збирання підписів на командах були відряджені й деякі члени президії Генеральної старшини таборової громади «Самостійна Україна». Того ж дня О.Скоропис-Йолтуховський виїхав до Зальцведеля, далі він мав відвідати Вецляр, і лише потім побувати у Раштаті. В усіх таборах він мав виступити на загальнотаборових вічах, обговорюючи «саму лінію домагань», які він мав потім обстоювати у Петрограді14.

Централя СВУ своїм листом від 4 квітня 1917 р. поінформувала Генеральну старшину, що військове міністерство Німеччини надіслало до комендатури табору спеціальний циркуляр, яким доручала останній зробити «всякі улекшеня до збираня підписів під наказом, не роблячи трудностей також при скликаню робітничих команд під час роботи»15. У цьому листі О. Скоропис-Йолтуховський також дякував Генеральній Старшині за енергію, яку вона виявила на етапі підготовки до збирання підписів, і визначив кінцевий термін проведення цієї кампанії - 20 квітня. На його думку, було дуже важливо, аби «наказ підписали всі Українці Раштатського району і на командах, куди заїздять Ваші мужі довіря. Коли не зберемо що найменше 10.000 підписів, то весь наш розмах проти Москаля піде на марно»16.

Крім того О.Скоропис-Йолтуховський просив уміщувати у кожному числі таборової газети інформацію про кількість щодня зібраних підписів, публікувати на останній сторінці імена підписантів із зазначенням номерів їх команд. Повідомляючи про свій приїзд до Раштату 10 квітня, він просив організувати зустріч з українсь-

\footnotetext{
13 ЦДАВО України. Ф. 4406. Оп. 1. Спр. 39. Арк. 13.

14 ЦДАВО України. Ф. 4406. Оп. 1. Спр. 39. Арк. 10.

15 Ibid. Арк. 17.

16 Ibid. Арк. 17.
} 
ким активом (членами Генеральної Ради і Старшини та «мужами довір'я»), а також скликати ввечері того ж дня «агітаційне віче» для роз'яснення полоненим політичної ситуації в Росії17.

Слід відзначити, що процес переконування полонених тривав зі значними труднощами, що було зумовлено неготовністю значної частини таборян зробити свій вибір на користь української справи. Російський самодержець зрікся престолу, але багатовіковий підневільний стан України фатально позначився на переважній більшості українців, які все ще вважали обстоювання національно-визвольних гасел небезпечною справою. В очах частини полонених підписання цього «мандату» означало цілковитий розрив з їх старими проросійськими уявленнями, яких вони не змогли позбутись - навіть перебуваючи довший час в українському таборі.

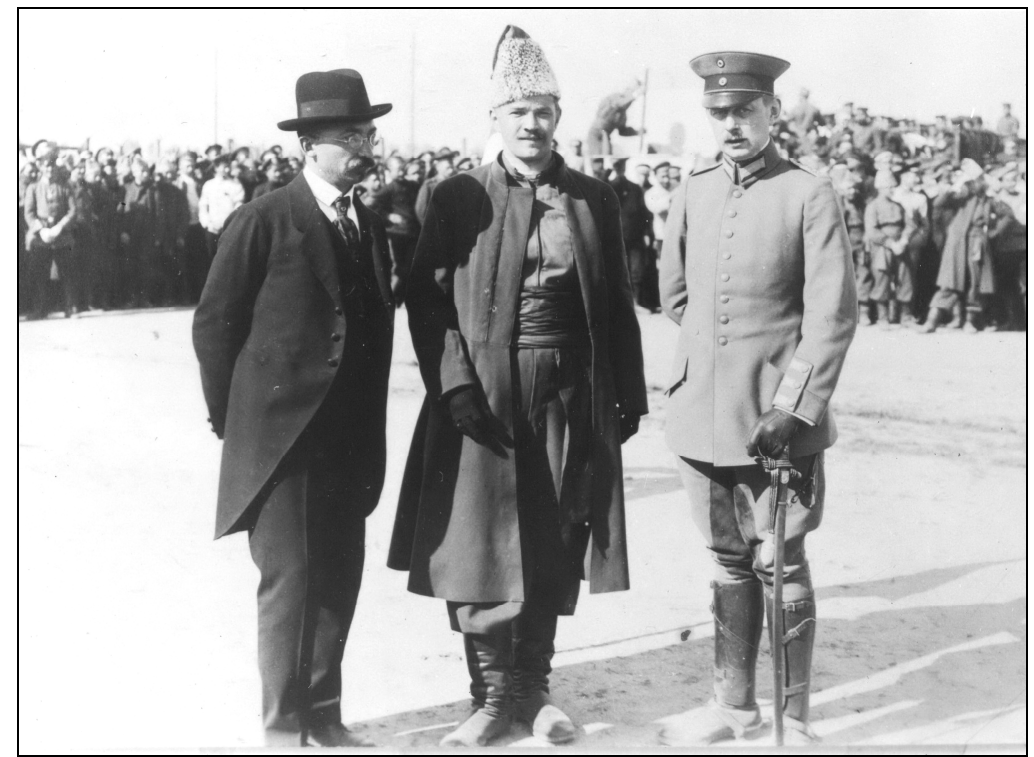

Puc. 1. Оригінальний підпис на зворотній стороні фотографії: «Отаман 1 Запорожського полка імені Т. Шевченка в товаристві Президента Союзу Визволення України n[ана] Скорописа i сот[ника] Люварса (треба: Люберса - авт.). Полков[ник] Шаповал, 27.4.1916 р., Раштат» (Архів ОУН в УІС (Лондон). Ф. 30. Од. зб. 1. Од. обл. 1)

Архівні документи рясніють повідомленнями «мужів довір'я», які у переважній більшості інформували про незадовільний хід збирання підписів на робітничих командах. Як йшлося у листі одного 3 них (А. Волосова) до голови табору Я. Тарасовського (від 9 квітня 1917 р.) - хоча команди отримали газети з підписними листами, значна кількість полонених заявляла, що підписувати їх «бояться або не годяться (не погоджуються - $a в m$.)», причому особливо їх непокоїла наявність у тексті пункту про Переяславську угоду. За висловом українського активіста, деякі команди «чортом дивились» на приїзд представника табору для збирання підписів, інші «не мають і не хотять мати наших часописів», виписуючи натомість «Рускій Вестник», консервуючи у такий спосіб свою малоросійськість 18.

А. Волосів гостро таврував у своєму листі «південних українців», зокрема херсон-

\footnotetext{
17 Ibid. Арк. 18.

18 ЦДАВО України. Ф. 4406. Оп. 1. Спр. 178. Арк. 55зв.
} 
ців, які «таки в більшости зволоч (сволота - aвт.), що й гидко дивитися на них», бо вони «в першу чергу в опозицію стають[...] і на якімсь чортовім жаргоні починають пояснювати, що вони за Україну не підпишуться». Спілкуючись 3 полоненими, А. Волосів підмітив, що «як тільки виступає опонент і починає тараторити, то я зразу кажу йому "чи ви товаришу не Херсонський?" і ще ні разу не помилився», і що йому «соромно за таких земляків». Такий стан справ спонукав А. Волосова зробити сумний висновок, що частина полонених у деяких командах (Ветельбрун та ін.) перебуває «на тім ступені, як півтора роки назад у таборі. Вчили би ся вони радо, але при тих условіях, як би про Україну їм не нагадували, соціальні думки їм можна привити, але що до національних, то...»19.

Ще один представник Раштату - полонений П. Поляків (член таборового Драматичного товариства), якого було делеговано для збору підписів в окрузі Еттенгайм, повідомляв про «дуже кепські» результати збору підписів. Він не приховував свою зневагу до неосвіченої частини полонених малоросів: «звичайна кобилка не хоче підписувати і говоре Бог зна що, а багато людей котрі состояли по ріжних організаціях, а навіть і провідники команд де які, не підписали із страху щоб на їх не гримали на командах». Відвідавши 12 команд, П. Поляків зібрав лише 20 підписів. Цей сумний «здобуток» не влаштовував його настільки, що він навіть зважувався підправити (фактично - фальсифікувати) цей результат. Маючи «при собі повністю імена і фамілії і лічні номера» П. Поляків повідомляв невідомому адресату про те, що йому «прийдеться самому підроблювати підписи бо інакше нічого не вийде»20.

Зараз достеменно неможливо точно встановити, чи дійсно він зважився на таке чи все ж таки відмовився від реалізації свого задуму. Також існує ймовірність того, що привезені ним підписні листи не були враховані Генеральною Старшиною, яка знала (з його ж листа) про фактичну кількість підписантів. Проте найголовнішим у цій історії $\epsilon$ інше - а саме непереможне бажання вихованих Раштатом українських активістів скріплювати й обстоювати українську ідею усіма можливим (і неможливими) засобами. Очевидно, що прагнення П. Полякова розбурхати темну солдатську масу, домогтись ствердження національних домагань українців перед Тимчасовим урядом Росії - заслуговують на цілковиту підтримку та схвалення, навіть якщо він при цьому у чомусь відійшов загальноприйнятих в європейських країнах принципів підрахунку голосів.

13 квітня 1917 р. на своїх надзвичайних зборах Генеральна рада громади «Самостійна Україна», яка представляла інтереси 12 тисяч полонених українців табору Раштат, розглянула питання про відрядження делегації до Петербургу з метою представництва інтересів полонених українців у Німеччині. За наслідками його обговорення було ухвалено рішення видати О. Скоропису-Йолтуховському наступний окремий «мандат», зміст якого суттєво відрізнявся від «фрайштадського наказу»:

«На підставі пунктів домагань, підписаних членами нашої Громади, Генеральна Рада як верховна політична інституція цілої громади, доручає Президентові Скорописові, перед московським правительством і всеросійськими зборами і де то буде вимагати Українська справа, заступати наші національні і політичні інтереси, згідно з політичною зрілістю нашої громади, котра домагається, аби доля України ні в якім разі не була рішена загальними Установчими зборами, а лишень українське питан-

19 Ibid. Арк. 55.

20 Ibid. Арк. 59-60. 
ня, як національне і політичне життя, а також відношення до російської і других держав - мусить бути вирішено Українськими Установчими Зборами, скликаними на підставі загального, рівного, тайного і безпосереднього голосування. Вибори мають бути проведені на території заселеної Українським народом. Українські Установчі Збори мають зібратися в нашій столиці Києві»21.

Таким чином раштатці цілком слушно наполягали на тому, що доля України мала вирішуватись не всеросійськими установчими зборами у Петрограді, а всеукраїнськими - у Києві, а делегати до них мали обиратись українцями на землях їх проживання. Таким чином, члени громади «Самостійна Україна» відкидали автономістські постулати, які були покладені в основу «наказу фрайштадців», і пропонували підвищити їх «градус» до рівня самостійницьких вимог (але знов таки - не заявляючи про це відкрито).

Вже наступного дня (14 квітня) Генеральна Старшина громади «Самостійна Україна» звернулась з листом (за підписом Я. Тарасовського) до всіх українських таборових представництв, заявивши про свій намір видати «окремий мандат» 0. Скоропису-Йолтуховському - з огляду на неясність тих вимог, які були початкове сформульовані Головною радою табору Фрайштадт. Раштатці просили громади інших українських таборів підтримати їх самостійницькі змагання, водночас вони, не бажаючи роз'єднувати голоси полонених, які паралельно збирались в усіх таборах під первинним текстом «мандату», зробили все аби максимально підтримати його опублікований варіант 22 .

Збір підписів тримав до 26 квітня, але не був фактично завершений і цього дня. Розіславши на команди 800 бланків 3 текстом мандату для О.СкорописаЙолтуховського, Генеральна Старшина отримала з них лише 310, в яких фігурувало 8268 підписів 23. При цьому таборовий провід у протоколі підрахунку підписів від 27 квітня 1917 р. полонених вказав на поважні труднощі, які перешкоджали їх збиранню. До них, зокрема, належали: надзвичайно незручний момент, коли майже всі полонені виїхали з табору до робітничих команд, а поштовий зв'язок ще не було налагоджено належним чином; короткий термін збирання підписів, коли у перші дні через дії комендатури не було можливим розпочати цю кампанію; необізнаність німецьких урядовців (які супроводжували команди) зі змістом і значенням цієї акції, що призводило до надіслання до табору незаповнених бланків, які навіть не пред'являлись полоненим; неможливість охопити всі команди, внаслідок чого значне число українців просто не знали про проведення цієї акції 24.

3 огляду на останнє, до табору надходили підписані бланки й після 26 квітня, що пояснює існування іншої цифри зібраних підписів - 852325. Між тим централя СВУ на початку травня 1917 р. подовжила термін збирання підписів, але скористатись цим раштатці вже не могли, бо раніше в одному з номерів таборового часопису було розміщено оголошення про завершення збирання підписів і подана їх загальна кількість. Більше того, у тому ж номері містилась повідомлення про те, «що ті підписі, які надходять тепер уже не так важні». Не вважали раштатці доцільним і наново відпра-

21 ЦДАВО України. Ф. 4406. Оп. 1. Спр. 40. Арк. 22; Спр. 39. Арк. 19; Спр. 111. Арк. 240-240зв.

22 ЦДАВО України. Ф. 4406. Оп. 1. Спр. 40. Арк. 21; Спр. 39. Арк. 20. Спр. 111. Арк. 239.

23 Розсвіт (Раштат). 1917. 28 квітня. Ч. 27 (92).

24 ЦДАВО України. Ф. 4406. Оп. 1. Спр. 39. Арк. 27.

25 ЦДАВО України. Ф. 4406. Оп. 1. Спр. 31. Арк. 3; див. також: Розсвіт (Раштат). 1917. 2 травня. Ч. 28 (93). 
вляти за підписами «мужів довір'я», до того ж існувала дуже мала ймовірність того, що та частина полонених, які не підписали «уповноваження» у квітні 1917 р., зробили би це цього разуㄹ․ Але $\epsilon$ підстави припускати, що таборовий секретаріат все ж таки враховував ті підписні листи, які надходили до табору впродовж травня 1917 р., бо остаточна ̈іх кількість (станом на 9 червня 1917 р.) склала 882927.

Збір підписів для уповноваженням О.Скорописа-Йолтуховського став першою серйозною перевіркою самостійницького потенціалу раштатської громади, яку вона успішно витримала. Загалом у трьох таборах (Раштат, Вецляр, Зальцведель) було зібрано 19004 підписів. Ще 4000 підписів було зібрано М. Меленевським серед полонених українців на австрійських землях ${ }^{28}$. Це дало підстави О.СкорописЙолтуховському звернувся до Української Центральної Ради у Києві (лист від 18 липня 1917 р.), наголосивши на тому, що «свідомі українські громадяни, які перебувають тепер у полоні, особливо ж ті, що згуртувалися у національних таборах, зустріли перемогу революції не як байдужі сторонні глядачі, а з одушевленєм, з вірою, що шлях до нашого відродження розчищений, що і на "нашій не своїй землі" настала пора державного будівництва» ${ }^{29}$.

У такий спосіб О.Скоропис-Йолтуховський сподівався підготувати собі повернення до Києва, розраховуючи на те, що УЦР підтримає його клопотання про в'їзд до Росії на урядовому рівні. Проте ці сподівання виявились марними, бо провід УЦР не мав бажання перейматись лобіюванням приїзду О.Скорописа-Йолтуховського до України через його «пронімецькість», а російська влада, відповідно, не вважала за доцільне поспішати з наданням йому дозволу на прибуття до Петрограда 3 огляду на його репутацію «мазепинця».

У зв'язку з цим О. Скоропис був змушений тривалий час перебувати у Стокгольмі, намагаючись все ж таки встановити контакти з керівництвом УЦР, діючи у цьому напрямку не лише з власної ініціативи, але й за проханням офіційного Берліну, який у цей час шукав контактів з українською владою. Але все було марним - голова УЦР М. Грушевський вперто уникав робити будь-які кроки назустріч Союзузо, побоюючись «спровокувати» росіян на жорсткі заходи щодо України.

У цій ситуації О. Скоропис-Йолтуховський приймає рішення «передати ці домагання, знявши з себе цю місію, Українській Центральній Раді в повній вірі, що Українська Центральна Рада доведе до відома революційної демократії Росії і обстоюватиме здійсненє їх цілою своєю силою і авторитетом». Зрештою, О. Скоропис так і не отримав згоди на в'їзд від російського уряду, і тому всі підписані листи, петиції, мандат були передані ним на збереження у Нобелівську бібліотеку Шведської академії наук у Стокгольмі 31 .

Отже, Лютнева революція у Росії зруйнувала більшість внутрішніх бар'єрів, які заважали до цього полоненим приєднуватись до української справи. Крім того вона стала могутнім чинником у справі поширення національної свідомості полонених не тільки в таборі, але й на робітничих командах, впливаючи навіть на тих, хто спочатку тримався осторонь культурно-просвітньої праці в таборі. У цьому контексті од-

\footnotetext{
26 ЦДАВО України. Ф. 4406. Оп. 1. Спр. 39. Арк. 34.

27 Ibid. Арк. 40.

28 ЦДАВО України. Ф. 1115. Оп. 1. Спр. 2. Арк. 120-121.

29 Ibid. Арк. 119.

30 Центральний держархів України в м. Львові. ф. 309. Оп. 1. Спр. 2020. Арк. 17-18.

31 ЦДАВО України. Ф. 1115. Оп. 1. Спр. 2. Арк. 123-124.
} 
ним з найважливіших досягнень громади «Самостійна Україна» стало проведення кампанії збору підписів для уповноваження О. Скорописа-Йолтуховського для участі у роботі майбутніх російських Установчих зборів, та вироблення для нього осібного мандату, яким була зафіксована самостійницька позиція полонених раштатців у питанні майбутньої російської конституанти. При цьому значна кількість таборян продемонструвала високу ступень національної та громадянської свідомості, успішно склавши цей «іспит» власної політичної зрілості.

Разом з тим слід відзначити, що вплив революційних подій у Росії справив на значну кількість полонених лише поверховий вплив, що обумовлювало їх неготовність рішуче розірвати з омертвілою спадщиною «руського мира». Їх малоросійськість не могла бути швидко демонтована, і тому всі зусилля українського активу табору достукатись до їх сердець залишались марними. Але й у цьому випадку члени таборової громади «Самостійна Україна» не припиняли своєї діяльності, спрямованої на національно-політичне освідомлення цієї частини полонених українців. Зрештою, подальший розвиток українського національно-визвольного руху спонукав більшість таборян зробити свій усвідомлений вибір на українства та підтримати гасла УНР.

\section{REFERENCES}

Kryvosheieva, L. (2009). Natsionalno-prosvitnia diialnist Soiuzu vyzvolennia Ukrainy $v$ taborakh viiskovopolonenykh ukraintsiv (1914-1918 rr.). [National education activities of the Union of the Liberation of Ukraine in the prisons of Ukrainian prisoners of war (1914-1918)]. (Candidate's thesis). Zaporizhzhia [in Ukrainian].

Nazaruk, Yu.S. (2004). Orhanizatsiino-politychna diialnist Oleksandra Skoropysa-Yoltukhovskoho sered polonenykh ukraintsiv u Nimechchyni ta Avstro-Uhorshchyni (1914-1917 rr.) [Organizationalpolitical activity of Alexander Scoropius-Yoltukhovsky among captives of Ukrainians in Germany and Austria-Hungary (1914-1917)] Naukovi zapysky Instytutu politychnykh $i$ etnonatsionalnykh doslidzhen, 26, 126-132 [in Ukrainian].

Nazaruk, Yu.S. (2009). Zrostannia politychnoi svidomosti polonenykh ukraintsiv u 1917 r.: vid avtonomizmu do samostiinosti [The growth of political consciousness of the captives of Ukrainians in 1917: from autonomy to independence] Pamiatky: arkheohrafichnyi shchorichnyk, 10, 62-68 [in Ukrainian].

Skoropys-Yoltukhovskyi, 0. (1917, 3 kvitnia). Do vsikh hromadian Rashtatskoho taboru [To all citizens of the Rashtatsky camp] Rozsvit (Rashtat), 21 (86) [in Ukrainian].

Sribniak, I. (1999). Poloneni ukraintsi v Avstro-Uhorshchyni ta Nimechchyni (1914-1920 rr.). [Prisoners of Ukrainians in Austria-Hungary and Germany (1914-1920)]. Kyiv [in Ukrainian].

Sribniak, I. (2014). Natsionalno-orhanizatsiina ta kulturno-prosvitnytska diialnist polonenykh ukraintsiv u tabori Rashtat (Nimechchyna) u 1915-1917 rr. [National-organizational, cultural and educational activities of the captured Ukrainians in the camp of Rastatt (Germany) in 1915-1917]. Siverianskyi litopys, 6 (120, lystopad-hruden), 309-324 [in Ukrainian].

Sribniak, I. (2017). Novitnia «Zaporizka Sich» na chuzhyni (tvorennia paramilitarnykh struktur v ukrainskomu tabori Rashtat, 1916 r.) [Newest «Zaporizhzhya Sich» in a foreign country (creation of paramilitary structures in the Ukrainian camp Rashtat, 1916)]. Eminak, 1(17), Vol. 1, 80-85 [in Ukrainian].

Sribniak, I. (2017). Poloneni ofitsery-ukraintsi tsarskoi armii v tabori Rashtat (Nimechchyna) u 1916 r.: hromadskyi ta osobystisnyi vymir taborovoho povsiakdennia [The captive officers of the Ukrainian Army in the Rastatt camp (Germany) in 1916: the public and personal dimension of the camp's daily life]. Eminak, 4 (20), Vol. 1, 35-40 [in Ukrainian].

Sribniak, I. (2017). «Vzhe ne odynytsi z pomizh Ukraintsiv, ale tysiachi...» (diialnist hromady «Samostiina Ukraina» v tabori Rashtat u pershii polovyni 1918 r.) [«Already no units among Ukrainians, but thousands...» (activity of the community «Independent Ukraine» in the camp of Rastatt in the first half of 1918)]. Mezhybizh, 1, Vol. 1, 345-352 [in Ukrainian].

Sribniak, I. (2018). Działalność narodowo-organizacyjna Związku Wyzwolenia Ukrainy w obozie jeńców armii cesarskiej Rastatt w Niemcach (1915-1918) [National-organizational activities of the Union of 
Liberation of Ukraine in the camp of the prisoners of the tsarist army Rastat in Germany (19151918)]. Wschodnioznawstwo, 231-242 [in Polen].

Terletskyi, 0. (1919). Istoriia ukrainskoi hromady v Rashtati 1915-1918 [History of the Ukrainian community in Rastatt 1915-1918]. T. 1. Kyiv-Liaiptsig [in Ukrainian].

\section{Ihor Sribniak}

(Borys Grinchenko Kyiv University, Kyiv, Ukraine)

ORCID: https://orcid.org/0000-0001-9750-4958

\section{Julia Nazaruk}

(Melitopol College Dmytro Motornyi Tavria State Agrotechnological University, Melitopol, Ukraine)

ORCID: https://orcid.org/0000-0002-4902-1764

\section{«If We Don't Collect at Least 10,000 Signatures, Then Our Whole Venture against the Muscovite Will Be for Nothing...» (Participation of Ukrainian Captives of Rastatt Camp in the All-Russian Revolutionary Movement, 1917)}

The relevance of the paper is in the need to show objectively the course of the signaturecollecting campaign to authorize 0.Skoropys-Yoltukhovskyi to represent the rights and interests of captive Ukrainian soldiers of Rastatt camp (Germany) before the Russian Provisional Government. The goal of this paper is to describe the organizational efforts of the «Independent Ukraine» camp community in that case, as well as to identify the factors that, on the one hand, contributed to that campaign, and on the other hand, complicated it significantly.

The objectives of the paper are to determine the peculiarities of the camp prisoners' reaction on collecting signatures initiative; establishing the forms and methods of communication of prisoners with the Ukrainian camp activists; evaluating the effectiveness of the subscription campaign, which directly correlated with the level of national and social awareness of various groups of captive Ukrainians.

While analyzing this problem, it should be born in mind that the February Revolution in Russia destroyed most of the internal barriers that prevented prisoners from joining the Ukrainian cause. Besides, it had become a powerful factor in spreading the national consciousness of prisoners not only in the camp but also in the work teams, influencing even those who initially kept aloof from cultural and educational activity in the camp. Consequently, a large number of camp prisoners showed a high degree of national and civil consciousness, having successfully passed that «test» for their political maturity.

However, it should be noted that the impact of the revolutionary events in Russia had only a superficial influence on the significant number of prisoners, and led to their decisive unwillingness to break off with the dead heritage of the «Russian world». Their malorosiistvo (Little Russia mentality) could not be quickly changed, so all efforts of the Ukrainian camp activists to reach their hearts remained in vain. But, even in this case, the members of the «Independent Ukraine» camp community did not cease their activities aimed at the national and political enlightenment of this part of Ukrainian captives. After all, the further development of the Ukrainian national liberation movement induced most camp prisoners to make their conscious choice for the Ukrainians and support the UNR slogans.

Keywords: captives, camp, newspaper, powers, O. Skoropys-Yoltukhovskyi, Rastatt, Germany 